\title{
Attracting visitors to ancient neighbourhoods
}

Aesthetic values and historicity are both pillars on which the development of tourism is mainly based (Zukin, 1995). At the European level, the historic city centres have attracted an important amount of tourists for centuries. However, apart from the most visited European cities, in recent decades, a set of secondary cities have developed interesting initiatives for urban regeneration and tourism promotion (Russo y Van der Borg, 2002).

The city of Plymouth located in the south of England constitutes an example of good practices in this field. Plymouth is a medium size, a multifunctional city with regional relevance and is placed in the most visited regions of England. Its geographical position guaranteed an historic role as a naval base and also as an important port in relation with migrations and colonial trade. Therefore, the city has a noticeable port character and strong relationship with military forces which contributes to define the current urban shape. The recent urban transformations are linked to enhancement plans in the waterfront and historic areas trying to upgrade the attractiveness of part of the city for the visitors (Lacaze, 1995).

The book here reviewed is the evolution of a doctoral thesis and; therefore, it addresses four research questions. The first one is oriented to study the evolution of the historic city. It follows the concerns on the current framework of the preservation of historic city as heritage asset; then, the analysis of the city tourist model and finally, the author focuses on how the different stakeholders and initiatives are related to the tourism development. For that purpose, its research is divided into four aspects: heritage and culture, tourism, urban planning and economy. As a result, a holistic approach is obtained through integral analysis far from sectoial perspectives. The author demonstrates his dexterity in producing his own graphic materials, mainly thematic maps and schemes on historical

\footnotetext{
${ }^{1}$ D. Barrera-Fernández (2016): Attracting visitors to ancient neighbourhoods. Creation and management of the tourist-historic city centre of Plymouth. UK, PhD Series, InPlanning, Gronningen, Netherlands, 293 pp.
}

aerial photographs. The use of the contrast between the black and white cartographic bases and the superposition of points, lines or coloured surfaces is very pleasant for the understanding of the text. Furthermore, the volume contains many interesting photographs.

The book is organised into six parts, followed by a set of conclusions. The volume is opened with an introductory chapter in which the methodology and the research questions are presented. The second chapter is devoted to a deep review of scholar contributions about the role of the historic city in Europe regarding its heritage values and the recent touristic trends. The next section is an outstanding summary of the city due to its conciseness and comprehensiveness; and as a consequence, it is really effective for readers who do not know the city of Plymouth. The fourth chapter is divided into two different sections; on the first part, the evolution of the interest in heritage preservation. This part part is characterised by its linear narrative from the outbreak of the Second World War, going through the aftermath of Plymouth Blitz and the subsequent Plan for Plymouth designed by Sir Patrick Abercrombie and James Watson (1943) in 1943 - and based on the model of Automotive City (Choay, 1983) - , and ending with the recent inner city regeneration focused on the heritage and tourism as an economic resource. The second part of the fourth chapter addresses the current framework of heritage protection under different perspectives; on the one hand, the conservation areas and listed buildings; on the other hand, analysing the heritage at risk.

The chapter number five is entitled Tourism in Plymouth's historic city and in its first part summarizes the history of tourist sector, whereas in the second is focused on the presence and significance of tourism and related activities. The final chapter is devoted to explaining the role of actors and initiatives involved in the management of the tourist-historic city. This chapter is based on fieldwork and qualitative analysis of plans and projects from the public administration, public-private agencies, pri- 
vate companies and third sector organisations and is split into four different parts according with the four aspects defined in the research questions established in the introduction: culture and heritage, tourism, urban planning and economic development.

The concluding remarks reflect the important role of some associations such as Old Plymouth Society and Plymouth Barbican Trust for the preservation of heritage values. Regarding the city's tourism history, Plymouth was not a classic seaside resort during the nineteenth century until World War II, after that, as consequences of the war, several facilities and attractions were destroyed. The Plan for Plymouth contributed to the elimination of existing built heritage in the city's central area; however, the Plan was no imposed as expected and finally, the Plymouth Barbican remain as a historic centre. The history and heritage is very important for the development of tourism in the city. Nevertheless, Plymouth is today the city having more listed buildings from this period outside London. The public-private partnerships played a key role as triggers for the tourism promotion and urban regeneration. Finally, Plymouth aspires to improve its presence in the tourism market with the implementation of a new brand: "Plymouth, Britain's Ocean City".

To sum up, the book reviewed, it is an example of how medium-sized European cities oriented their histori- cal heritage towards tourism promotion seeking to obtain an economic diversification in which the public-private partnerships has a leading part (Troitiño Vinuesa, 2010). The author highlights the integrative approach taking into account different aspects such as culture, urban planning and economic development.- ÍCARO OBESO MUÑIZ

\section{REFERENCES}

CHOAY, F. (1983): El urbanismo: utopías y realidades. Lumen, Barcelona.

LACAZE, J. P. (1995): La ville et l'urbanisme: un exposé pour comprendre, un essai pour réfléchir. Flammarion.

Russo, A. P., y J. VAN DER BORG (2002): “Planning considerations for cultural tourism: a case study of four European cities", Tourism management, 23(6), 631-637.

Troitiño Vinuesa, M. Á., y L. Troitiño TorralbA (2010): "Historic cities and tourism: functional dynamics and urban policy", Open Urban Studies Journal, 3, 47-57.

Watson, J. P., P. Abercrombie, L. D. Stamp y G. W. ROBINSON (1943): A plan for Plymouth. Underhill, ltd.

ZuKIN, S. (1995): The cultures of cities. Oxford: Blackwell. 
